\title{
Bathyal sponges from the late Early Miocene of the Vienna Basin (central Paratethys, Slovakia)
}

\author{
Magdalena Lukowiak • Andrzej Pisera • \\ Ján Schlögl
}

Received: 14 January 2013/Accepted: 1 August 2013/Published online: 28 August 2013

(C) The Author(s) 2013. This article is published with open access at Springerlink.com

\begin{abstract}
Here we report, for the first time, a very rich and diversified sponge assemblage from late Early Miocene deposits of a central part of the Vienna Basin (Paratethys) in Slovakia. Bodily preserved sponges are described as a new genus and species Paracinachyrella fossilis (Tetiliidae, Demospongiae). Dissociated spicules reveal the presence of the "soft" demosponges that belong to families Tetillidae, Theneidae, Geodiidae, Samidae, Thrombidae, Thoosidae, Agelasidae, Myxillidae, Bubaridae, and Tedaniidae, the lithistid family Pleromidae, and an undetermined rhizoclone-bearing lithistid. Fragments of dictyonal skeleton indicate the presence of hexactinellid sponges that belong to the families Farreidae and Euretidae, and lychniscosan sponges. We estimate that at least 16-19 different species of siliceous sponges inhabited this region of the Central Paratethys during the latest Burdigalian. Most of these sponges are reported for the first time from the Miocene of the Paratethys. This sponge fauna has clear Tethyan affinities and indicates the existence of connection between Paratethys and Tethys during the latest Burdigalian, as well as the presence of open marine, deepwater, bathyal conditions in this part of the Vienna Basin.
\end{abstract}

M. Łukowiak · A. Pisera $(\bowtie)$

Institute of Paleobiology, Polish Academy of Sciences,

ul. Twarda 51/55, 00-818 Warszawa, Poland

e-mail: apis@twarda.pan.pl

M. Łukowiak

e-mail: mlukowiak@twarda.pan.pl

J. Schlögl

Department of Geology and Paleontology, Faculty of Natural

Sciences, Comenius University, Mlynská Dolina,

Bratislava 842 15, Slovakia

e-mail:schlogl@nic.fns.uniba.sk
Keywords Porifera - Spicules - Demospongiae · Lithistida $\cdot$ Hexactinellida $\cdot$ Burdigalian .

New species

Kurzfassung Wir beschreiben eine neue, sehr reiche und diverse Schwamm-Assoziation aus Ablagerungen des späten Unter-Miozän des zentralen Teils des Wiener Beckens (Paratethys) in der Slowakei. Körperlich Schwämme werden als neue Gattung und Art Paracinachyrella fossilis (Tetiliidae, Demospongiae) beschrieben. Disassoziierte Nadeln belegen die Anwesenheit von "weichen" bzw. skelettlosen Demospongiern, die zu den Familien Tetillidae, Theneidae, Geodiidae, Samidae, Thrombidae, Thoosidae, Agelasidae, Myxillidae, Bubaridae und Tedaniidae sowie zu den lithistiden Familien Pleromidae und einem unbestimmten Rhizoclon-tragenden Lithistiden gehören. Bruchstücke dictyonaler Skelette sprechen für die Anwesenheit hexactinellider Schwämme, die zur Familie Euretidae und lychniscosen Schwämmen gehören. Wir schätzen, dass mindestens 16-19 verschiedene Arten von kieseligen Schwämmen diese Region der zentralen Paratethys während des jüngsten Burdigal besiedelten. Die meisten dieser Schwämme werden zum ersten Mal aus dem Miozän der Paratethys beschrieben. Diese Schwamm-Fauna zeigt klare Affinitäten und spricht für eine offene Verbindung zwischen Paratethys und Tethys während des jüngsten Burdigal und impliziert, dass offen marine, tiefe, bathyale Bedingungen in diesem Teil des Wiener Beckens vorherrschten.

Schlüsselwörter Porifera $\cdot$ Spiculae . Demospongiae $\cdot$ Lithistida $\cdot$ Hexactinellida . Burdigal · neue Art 


\section{Introduction}

Sponges are rarely reported from the Miocene of the Paratethys, and usually only as loose (dissociated) spicules (Alexandrowicz and Tomaś 1975; Alexandrowicz 1978; Riha 1982, 1983; Hurcewicz 1991; Pisera and Hladilová 2003). This rarity is not real but caused rather by lack of studies and nonpreservation (in shallow-water carbonate deposits). Here we report a rich assemblage of siliceous sponges from the Lower Miocene deposits of the Slovakian sector of the Vienna Basin. The material is mainly composed of dissociated spicules, but several completely preserved specimens have also been found, allowing for precise determination and description. The fauna of sponges described here is the first from the Miocene of the Paratethys which is so well preserved and diversified, allowing for ecological and biogeographical interpretations.

\section{Geographical and geological setting}

Sponges and rock samples for micropaleontological studies were collected at the Cerová-Lieskové locality in the western part of the Slovak Republic. The outcrop is situated at the foothills of the Malé Karpaty Mountains forming the actual eastern margin of the central Vienna Basin (Fig. 1). During the Miocene, this basin was part of the Central Paratethys Sea. Upper Burdigalian ("Karpatian" in the Paratethys scale) sediments, assigned to the Lakšárska Nová Ves Formation (Špička and Zapletalová 1964), are well exposed in a former clay pit, represented by massive, locally laminated, calcareous clays and clayey silts with thin tempestite intercalations (up to $10 \mathrm{~mm}$ thick) and several thin sandstone/siltstone layers. The studied section is more than $15 \mathrm{~m}$ thick. Macrofossil assemblages comprise vertebrates, mainly teleosts, and a wide spectrum of invertebrates-bivalves, gastropods, scaphopods
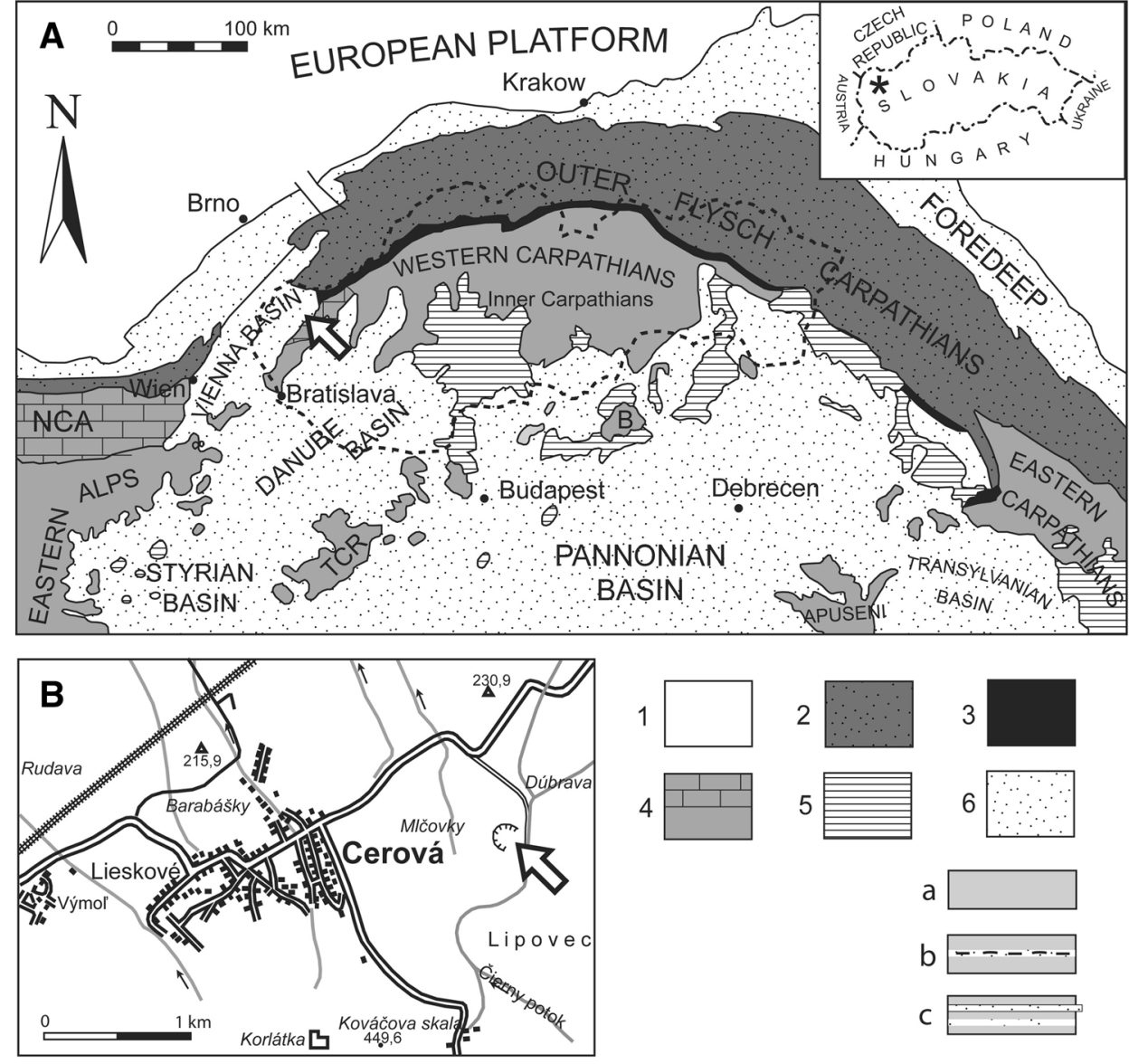

2

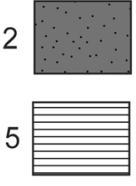

\section{3}

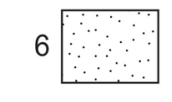

a

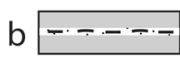

C
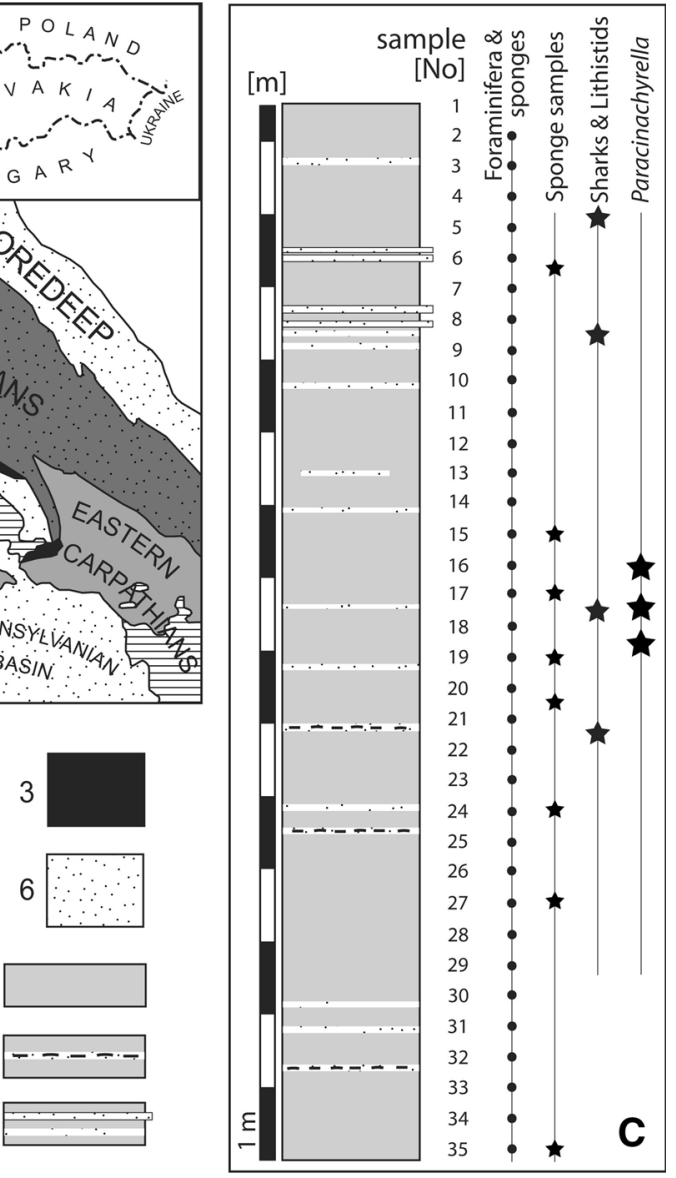

siltstone/sandstone layers or silt lenses. Small circles indicate presence of sponge spicules within the samples taken for foraminiferal analyses. Small asterisks localize samples taken for sponge assemblages (400-1,000 g), medium asterisk presence of lithistid sponges in "shark samples" (more than $30 \mathrm{~kg}$ ), large asterisks articulated Paracinachyrella specimens (map and section based on Schlögl et al. 2011, modified) 
(Harzhauser et al. 2011), cephalopods (Schlögl et al. 2011a), decapods (Hyžný and Schlögl 2011), isopods (Hyžný et al. 2013), barnacles (Harzhauser and Schlögl 2012), regular and irregular echinoids, asteroids, ophiuroids, siliceous sponges, and solitary corals. Microfossil suites include benthic and planktonic foraminifera, radiolarians, sponge spicules, ostracods, crinoid ossicles, coleoid statoliths, fish otoliths, shark teeth (Underwood and Schlögl, in press), and extremely abundant diatoms.

Age assignment of these deposits relies on the cooccurrence of the foraminifera Uvigerina graciliformis Papp and Turnovsky, 1953 and Globigerinoides bisphericus Todd in Todd, Cloud, Low and Schmidt, 1954 and the absence of the genus Praeorbulina Olsson, 1964. The first appearance datum of $U$. graciliformis marks the base of the "Karpatian" stage (Cicha and Rögl 2003), while that of G. bisphericus is within zone M4b of Berggren et al. (1995), correlating with the upper "Karpatian". The appearance of Praeorbulina marks the beginning of the Middle Miocene. The regional Paratethyan "Karpatian" stage has consistently been considered to be the timeequivalent of the latest Burdigalian (Rögl et al. 2003; Piller et al. 2007).

\section{Materials and methods}

Most of the sponges investigated here are represented by loose spicules only, but several specimens (at least one demosponge species) are preserved intact but flattened. After being photographed, a small part of the specimens was treated in $\mathrm{HCl}$ to obtain clean spicules for study under scanning electron microscopy (SEM, Institute of Paleobiology). To search for microscleres, the surface of the specimens was scratched with a brush, and the material was deposited directly on a SEM stub for further investigation.

Dissociated spicules occurring in the sediment were obtained from samples containing 400-1,000 g of sediment. Each sample was dissolved in a $10 \%$ solution of hydrochloric acid, with the residue subsequently dried. In the next step, the residue was treated with hydrogen peroxide, washed through $0.063-\mathrm{mm}$ mesh, and dried. This part of the process was repeated several times. Finally, the residuum was cleaned in an ultrasonic bath. As a result of this method, each sample could be reduced to $0.15-0.2 \%$ of its original weight. Such residue was screened under a binocular microscope, and all the morphological types of spicules collected were subsequently attached to a stub and investigated by SEM.

All the investigated material is stored in the Slovak National Museum in Bratislava, acronym SNM Z.

\section{Systematic paleontology}

Both hexactinellid and demosponge spicules were common in the investigated residue, but demosponges dominated and were more diversified. Apart from dissociated spicules, several completely preserved demosponge specimens were also collected, and some of them could be confidently determined. These are formally described below, followed by a taxonomic interpretation of loose spicules.

Phylum Porifera Grant, 1836

Class Demospongiae Sollas, 1885

Order Spirophorida Bergquist and Hogg, 1969

Family Tetillidae Sollas, 1886

Genus Paracinachyrella gen. nov.

Derivation of the name: referring to the affinity to the Recent genus Cinachyrella Wilson, 1925

Diagnosis: tetillid sponges with protriaenes, anatriaenes, and strongyloxeas as megascleres and raphides as microscleres

Paracinachyrella fossilis sp. nov. (Fig. 2)

Derivation of the name: referring to the fact that it is a fossil sponge

Holotype: specimen SNM Z21 here illustrated (Fig. 2A, C)

Type locality and horizon: Cerová-Lieskové section (Slovakian part of the Vienna Basin, central Paratethys), Karpatian (late Early Miocene), layer 16

Material: two specimens and several fragments, all flattened and/or cross-sections with spicules preserved in original radial arrangement (layers 16-19)

Diagnosis: as for the genus

Description: Sponge with globular/ovoid morphology (about $5 \mathrm{~cm} \times 3 \mathrm{~cm}$ ) of the body and radially arranged spicules (Fig. 2A). The megascleres are protriaenes, anatriaenes (always broken), and long oxeas with one end blunt (strongyloxeas) that are $550 \mu \mathrm{m}$ (Fig. 2B-D) radiating outwards from the center of the sponge, the triaenes with long and slender rhabdom (always broken) and cladi of about $150 \mu \mathrm{m}$ in diameter. Microsclere spicules are bundles of small, slender raphides (trichodragmas) up to $80 \mu \mathrm{m}$. Apart from these typical tetillid spicules, we found fusiform oxeas that may or not belong to this sponge.

Remarks: This very well-preserved, articulated, flattened sponge body possessing such a set of spicules (raphid microscleres and triaene megascleres), as well as the ovoid morphology and radial arrangement of spicules, allow us to assign the studied sponges to the family Tetillidae Sollas, 1886. The presence of ana-, protriaenes, and strongyloxeas, as well as raphides as microscleres, suggests close affinity 

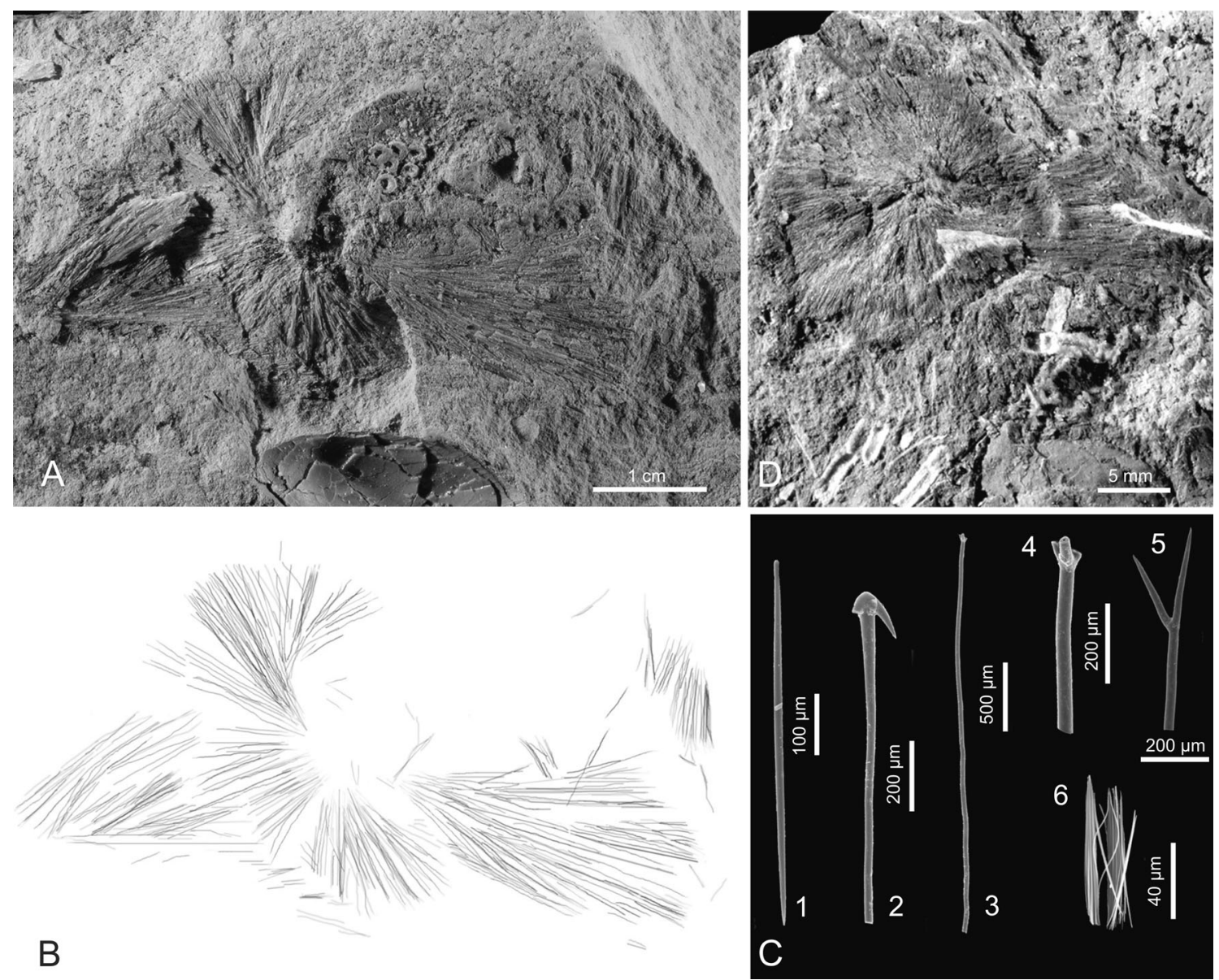

Fig. 2 Paracinachyrella fossilis gen. et sp. nov. A Articulated sponge body, holotype specimen SNM Z21. B Diagram of arrangement of spicules in the holotype. $C$ Spiculation of the holotype: $C 1$,

with the genus Cinachyrella Wilson, 1925. We also noted numerous sigma microscleres, but they must clearly be a contamination. The thick, fusiform oxeas may also be a contamination or belong to a specialized cortical zone known in Cinachyrella, but we were unable to prove this. Only the lack of oxeas and sigmaspires (that may be simply not found) differentiate the studied sponge from the genus Cinachyrella. Taking into consideration these differences in spiculation, as well as the Miocene age of the studied material, we decided to propose a new genus and species for the studied sponges. Earlier, the first fossil representatives of Tetillidae were reported by Schrammen (1910) from the Upper Cretaceous of Germany. He described a new genus Tetilliopsis (with two new species) that are spherical sponges with a radial arrangement of long oxeas and protriaenes, but without observed microscleres.

\section{Dissociated demosponge spicules}

Loose nonlithistid demosponge spicules were moderately frequent, constituting about half of the investigated sponge strongyloxea; $C 2$, anatriaenes; $C 3-C 5$, protriaenes; $C 6$, raphides (trichodragmas) microscleres; $D$ Articulated sponge body, specimen SNM Z22

spicules in the studied assemblage. They occurred in all studied samples. The spicules produced by Demospongiae are characterized by monaxial and/or tetraxial symmetry (Hooper and Soest 2002).

The most abundant spicule types were monaxons, including oxeas and styles (Fig. 3A-E), but simple triaenes (Fig. 3F, G) were also frequent. Unfortunately, precise taxonomic assignment of these morphologically simple spicules is difficult or even impossible because they can appear in many different demosponge groups. Such spicules, with low diagnostic value, are here only illustrated but without precise taxonomic assignment.

This is also the case of the spheraster (Fig. 3L-N, R) and triods (Fig. 3H, I), because they can appear in a wide array of demosponges. Sigma microscleres (Fig. 3P, Q) may belong to many distinct taxa within the Poecilosclerida, and the short-shafted dichotriaenes (Fig. 3K) belong, most probably, to the order Astrophorida. The calthrops (Fig. 3O) may belong to the Calthropellidae Lendenfeld, 1907 but also appear in other taxa, e.g., Pachastrellidae Carter, 1875. Anthasters (Fig. 3S, T) appear, e.g., in the 


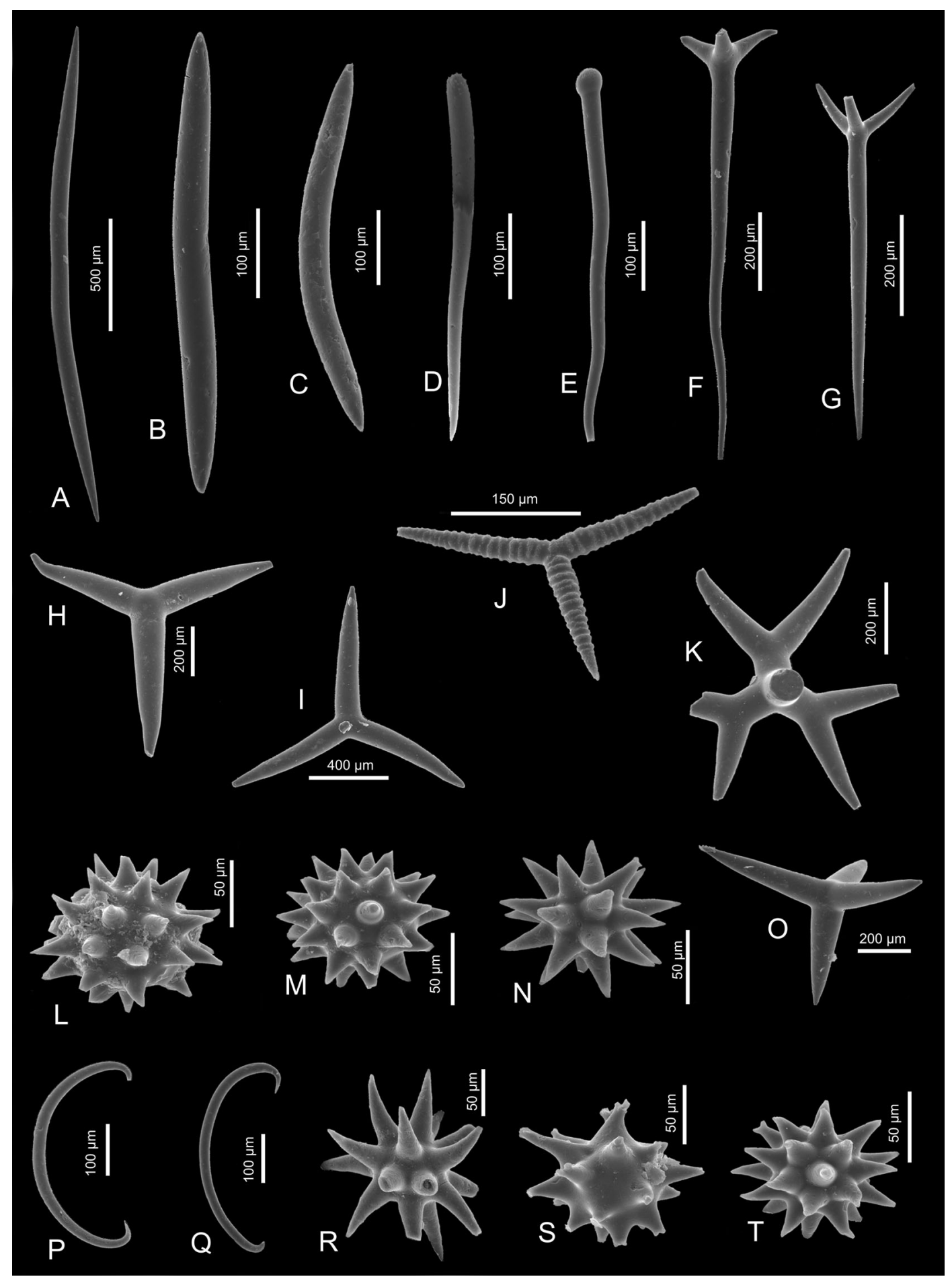

Fig. 3 Loose demosponge spicules: $A-C$ different types of oxeas; $D, E$ styles; $F, G$ triaenes; $H, I$ triods; $J$ cricotriod of Annulastrella Sollas, 1886; $K$ dichotriaene; $L-N, R$ spheraster; $O$ calthrop; $P, Q$ microsclere sigmas; $S, T$ anthasters

Hadromerida. On the other hand, there are also some very characteristic morphological types of spicules in the studied material that allow assignation to a particular taxon, and these are discussed below.

\section{Theneids}

The triactinal, annulate spicules (cricotriods) closely resemble those of astrophorid Annulastrella Sollas, 1886 
(Fig. 3J) (Theneidae Carter, 1883). The spicule is particularly similar to those of Annulastrella ornata (Sollas, 1888) (previously described as Vulcanella). Today, this species is noted from eastern Atlantic waters (the Azores and Cape Verde) (Boury-Esnault 2012). Similar fossil spicules were already described from the Miocene of Bahamas by Bukry (1978, pl. 13, figs. 17, 20). There are also some Triassic and Cretaceous spicules (annulate microxeas and plesiasters) of Monilites Carter, 1871b (family unknown) that resemble Vulcanella spicules (see Wiedenmayer 1994).

\section{Tetillids}

In the studied samples, apart from wholly preserved sponges belonging to Tetillidae, described above, there were also loose spicules that may be assigned to tetillids. These are numerous anatriaenes with cladome up to $100 \mu \mathrm{m}$ in diameter (Fig. 4A-C), and slender protriaenes with cladome up to 200-300 $\mu \mathrm{m}$ long (Fig. 4D, E) closely resembling those of Recent tetillids. Also sigmaspire microscleres (up to $400 \mu \mathrm{m}$ ) (Fig. 4G, H) were found, but they may belong to other sponges. There were also some heavily spined, about 300- $\mu$ m-long, oxeas called acanthoxeas (Fig. 4F), which resemble those of the genus Acanthotetilla Burton, 1959, but similar forms may occur also in the poecilosclerid Histodermella Lundbeck, 1910 (family Coelosphaeridae Dendy, 1922). Today, tetillids are cosmopolitan in all oceans and all depths (Hooper and Soest 2002). Spicules that may be undoubtedly assigned to tetillids are known since the Cretaceous (Wiedenmayer 1994).

\section{Geodiids}

Ovoid spicules called sterrasters, with numerous fused rays, their endings with the characteristic stellate terminations (Fig. 4M, N, Q), also appeared in the studied material. These spherical microscleres were over $100 \mu \mathrm{m}$ in size. Additionally, the studied sample contained triaenes up to about $900 \mu \mathrm{m}$ long (Fig. 4K, L), and various spherasters up to $100 \mu \mathrm{m}$ in diameter (Fig. 4I, J). Such a set of spicules is characteristic for the astrophorid family Geodiidae, Gray 1867. Additionally, some astrose spicules $(130-150 \mu \mathrm{m}$ in diameter) (Fig. 4O, P) were found that also belong to the order Astrophorida. Sponges belonging to the Geodiidae bear also various styles, but if isolated, they are not characteristic enough to be assigned as geodiid's. Unfortunately, in this case, more precise taxonomic assignment of all the above geodiid spicules to a particular lower taxon is not possible due to the fact that present-day taxonomy of this family is based not only on spicule morphology but also on the disposition of spicules in the sponge body (Uriz 2002a). Today, geodiid sponges occur worldwide and inhabit a wide bathymetric range, from very shallow to bathyal depths. They live on soft bottoms, as well as in caves and overhangs in the sublittoral zone (Uriz 2002a). Undoubted geodiid sterrasters are common in the fossil record since the Cretaceous (Wiedenmayer 1994). Bodily preserved specimens of Geodia were described by Finks et al. (2011) from the Eocene of North Carolina, USA.

\section{Samids}

Numerous amphitriaenes-double triaenes with short rhabds bearing two opposed cladomes (Fig. 5A-D)-were also found among the Slovakian spicules. These spicules are over $200 \mu \mathrm{m}$ in largest dimensions, and closely resemble those of the cosmopolitan, excavating, Holocene samid species Samus anonymus Gray, 1867 (Sollas 1888). Today, sponges of this monotypic spirophorid taxon are reported from submarine caves at shallow depths, and excavate limestone substrates, from many parts of the world (for more details see Hooper and Soest 2002). They have been noted recently in the Miocene of Portugal (Pisera et al. 2006), but are known at least since the Eocene (Wiedenmayer 1994).

\section{Thrombids}

The astrophorid family Thrombidae Sollas, 1888 includes only two genera and six species (Uriz 2002b; Gomez 2006). They are characterized by having spiny trichotriaenes with dimensions intermediate between those of megascleres and microscleres, often with clads divided dichotomously or trichotomously, and streptaster microscleres that are not always present (Uriz 2002b). Only acanthotrichotriaenes (Fig. 5E, F) were found in our material, with cladomes up to $80-100 \mu \mathrm{m}$ in diameter, that closely resemble those of the Recent species Thrombus abyssi Carter, 1873. No streptaster microscleres were found among the Slovakian spicules. Today, thrombids inhabit a wide range of depths but are mostly found in the bathyal zone of the Atlantic, Mediterranean, and Pacific (Hooper and Soest 2002), while the species T. abyssi inhabits the Atlantic and Indo-Pacific Oceans (Uriz 2002b). The oldest fossil occurrence of the genus is from the Late Eocene of New Zealand by Hinde and Holmes (1892), who described such spicules without any taxonomical attribution.

\section{Thoosids}

Thoosidae Cockerell, 1925 is characterized by the presence of oxeas, styles, or strongyles as megascleres, and microrhabds and/or amphiasters, or both, as microscleres (Rützler 2002). In the studied sample, there were rare, 


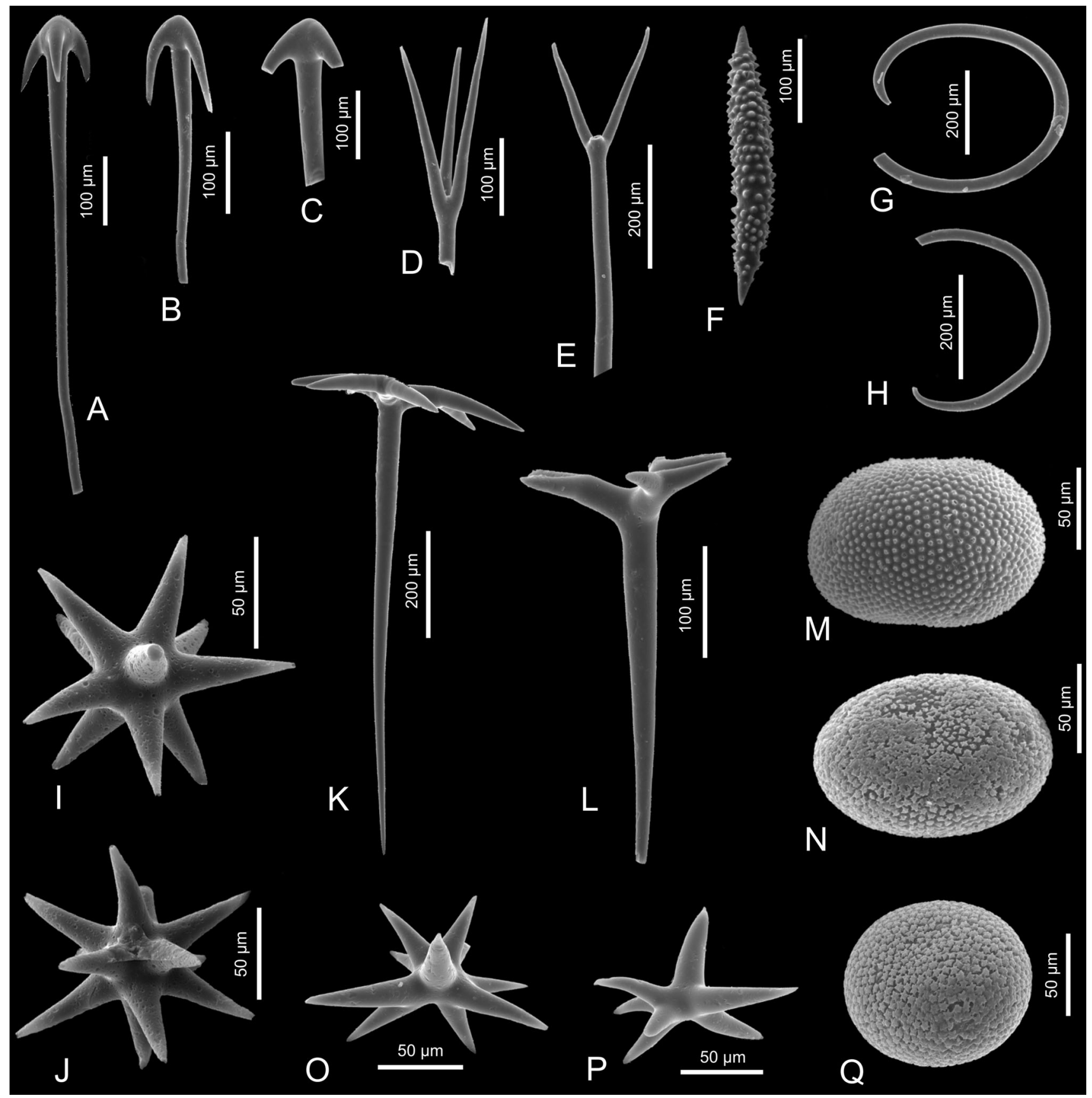

Fig. 4 Loose demosponge spicules: $A-C$ anatriaenes of the spirophorid family Tetillidae; $D, E$ protriaenes of the spirophorid family Tetillidae; $F$ acanthoxea of the spirophorid Acanthotetilla Burton, 1959 (family Tetillidae) or poecilosclerid Histodermella Lundbeck, 1910 (family Coelosphaeridae); $G, H$ sigma microscleres, probably of

tuberculated, about 500- $\mu$ m-long oxeas (Fig. 5G) that closely resemble those of Recent species Alectona wallichii Carter, 1874. Sponges belonging to this species are rare and rather small, and live cryptically inside calcareous substrates (Rützler 2002). They were noted from Hawaii (Vacelet 1999) and southern coasts of the African Continent (Van Soest et al. 2012). The spicules are almost the spirophorid family Tetillidae; $I, J, O, P$ oxyasters of the family Geodiidae (order Astrophorida); $K, L$ triaenes of the family Geodiidae (order Astrophorida); $M, N, Q$ sterraster microscleres of the family Geodiidae (order Astrophorida)

identical to those described from the Recent by Vacelet (1999). Pisera et al. (2006) described identical spicules from Miocene deposits of Portugal and assigned them also to A. wallichii. A situation such as that described, where there is a worldwide distribution of a species today, with apparent long geological history, suggests that we are dealing with a species complex. 


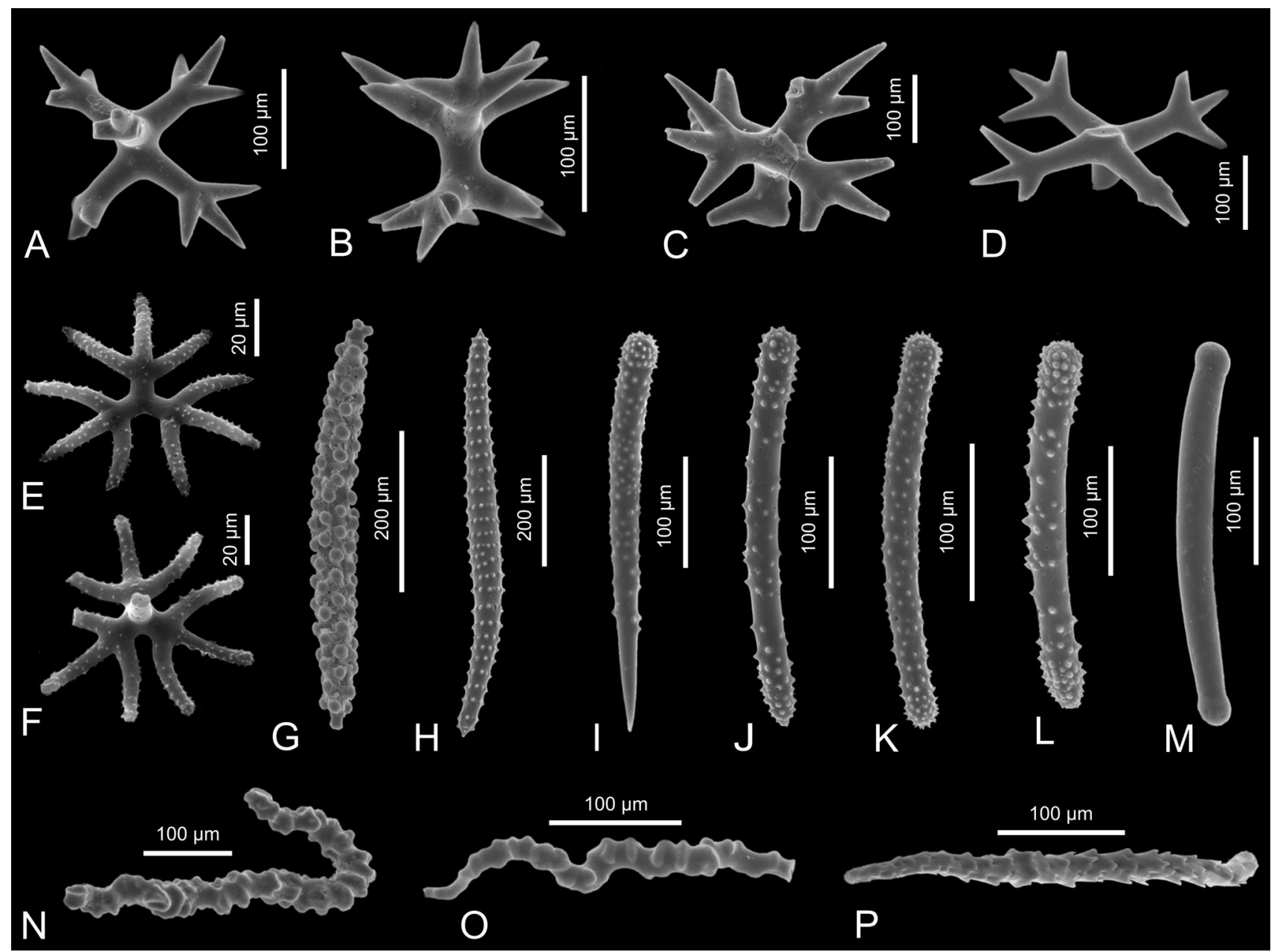

Fig. 5 Other demosponge spicules: $A-D$ amphitriaenes of Samus cf. anonymus Gray, 1867, family Samidae (order Spirophorida); E, $F$ acanthotrichotriaenes of Thrombus Sollas, 1886, family Thrombidae (order Astrophorida); $G$ tuberculated oxea of Alectona Carter, 1879, family Thoosidae (order Astrophorida); $H$ verticillate oxea of Agelas Duchassaing and Michelotti, 1864, family Agelasidae (order Agelasida); $I-K$ acanthostyles $(I, J)$ and acanthostrongyle $(K)$ of
Ectyonopsis Carter, 1883, family Myxillidae (order Poecilosclerida); $L$ acanthostrongyle of Ectyonopsis Carter, 1883, family Myxillidae (order Poecilosclerida); $M$ tylote of the family Tedaniidae (order Poecilosclerida); $N, O$ tuberculated monaxons of Monocrepidium Topsent, 1898, family Bubaridae (order Halichondrida); $P$ diactine (broken) ?hexactinellid (Amphidiscosida) spicule
Agelasids

Other soft demosponge spicules that occurred sporadically in the studied material belong to the family Agelasidae Verrill, 1907. Although the most common morphotype in this family are acanthostyles, in some species there are verticillate oxeas present (Fig. 5H) with concentric whorls of the tubercles, like those of Recent Agelas axifera Hentschel, 1911. So far, agelasids have been described from tropical Atlantic and Indo-West Pacific waters, with a single Australian and a single Mediterranean species, with the deepest occurrence at $150 \mathrm{~m}$ (Van Soest 2002a). Agelasid spicules are known since the Cretaceous (Wiedenmayer 1994).

\section{Myxyllids}

The family Myxillidae Dendy, 1922 was represented among the studied spicules by rare acanthostyles and acanthostrongyles. Both the acanthostrongyles and acanthostyles possess echinated surface, becoming more densely sculptured at the ends of the spicule (Fig. 5I-L). These spicules with mucronate ends are identical to those of Recent myxillid Ectyonopsis Carter 1883. Today, this genus is reported from rather shallow, temperate and cold waters (Van Soest 2002b) from the Southern Ocean (Van Soest et al. 2012), with one exception only. Similar spicules were described by Schrammen (1924) from the Cretaceous of Germany, and Mostler (1990) from the Jurassic of Austrian Alps. 


\section{Bubarids}

Other "soft" demosponge spicules found in the studied material were rare tuberculated, meandering, diactinal spicules (monaxons) of $300 \mu \mathrm{m}$ in length (Fig. $5 \mathrm{~N}, \mathrm{O}$ ). They are almost identical to those of the halichondrid family Bubaridae Topsent, 1894. Despite the fact that there were no other spicules characteristic of bubarids noted (such as long, smooth, slightly curved styles and/or slightly curved subtylostyles or tylostyles), the presence of these tuberculated diactinal spicules clearly indicates the presence of the genus Monocrepidium Topsent, 1898 in the studied material. Most genera of these encrusting sponges with hispid surface are found today in the east Atlantic, Mediterranean, and Indian Ocean, and are restricted to rather deep waters (Alvarez and Soest 2002). Spicules that resemble those here described and that may belong to the same taxonomical group were reported from the uppermost Triassic by Mostler (1986), and from the Cretaceous by Schrammen (1924).

\section{Tedaniids}

In our material, spicules that may belong to the poecilosclerid family Tedaniidae Ridley and Dendy, 1886 were also found. These are tylotes (350 $\mu \mathrm{m}$ in length) (Fig. 5M). Tedaniids are encrusting, massive or digitate sponges found predominantly in tropical and warm-temperate waters of the Atlantic, Indian, and Pacific Oceans on rocks and stones in shallow, littoral waters up to $100 \mathrm{~m}$ deep (Van Soest 2002a, b).

\section{Lithistids}

In paleontological literature, this group of sponges is treated as the formal order Lithistida Schmidt, (1870), but it is, in fact, a highly polyphyletic group of sponges characterized by the occurrence of articulated choanosomal spicules of various shapes and geometries, called desmas (Pisera and Lévi 2002a). For this reason, lithistids are treated in the zoological literature as a useful but informal group, and their formal rank should be abandoned. Various lithistids are very common in the fossil record since the Ordovician (Pisera 2006).

Lithistid spicules are very rare at Cerová and have been found in only two larger samples of sediment (samples 8-9 and 21-22, more than $50 \mathrm{~kg}$ of washed sediment). Moreover, they were very rarely observed also in samples $4-5$ and 17-18 (a few small fragments for more than $50 \mathrm{~kg}$ of sediment). One rhizoclone desma (Fig. 6F) and several typical megaclone desmas (Fig. 6G, I) have been found. These are the first occurrences of lithistid sponges in the Miocene of the Paratethys. Rhizoclones occur in various families of lithistid sponges (Pisera and Lévi 2002a), thus offering no precise taxonomic information. On the contrary, megaclones are very characteristic (Pisera and Lévi 2002b) and indicate the presence of Pleroma Sollas, 1888. Today, this genus is common in the SW Pacific, very rare in the tropical western Atlantic, and recently has also been found in the Indian Ocean, off Western Australia (Pisera, unpublished data). Fossil pleromids are very common in the Late Cretaceous deposits of Europe, and have been also noted (Pisera, unpublished data) in the Eocene of Spain and the Pliocene of Sardinia, but interestingly, appear to be absent from the Mediterranean Sea today. Both lithistids with rhizoclones and those that represent the genus Pleroma are today deep-water dwellers, usually at several hundred meters depth in tropical areas (Pisera and Lévi 2002b). They prefer hard substrates, which are missing in the investigated sediment, what may suggest that these spicules were transported.

Disassociated hexactinellid spicules

The hexactinellid (Hexactinellida Schmidt, 1870) spicules found and that occur in all studied samples are mostly pentactines and hexactines that are interpreted as dermal and/or gastral spicules of the order Hexasterophora. Based on their morphology and sculpture, there are at least two different species represented. Smooth pentactines with slender rays (Fig. 7A, B) are less common. Relatively heavily tuberculated pentactines and hexactines (Fig. 7C-I) are the most common hexactinellid spicules, clearly belonging to a different species. Apart from these spicules, larger samples of sediment contained fragments that belong to hexasterephoran hexactinellids with fused (dictyonal) skeletons. Those that are smooth, and clearly composed of one layer bearing tuberculated spines on one side (Fig. 6A, B), belong clearly to one species, representing family Farreidae Gray, 1872, most of Farrea Bowerbank, 1862. This genus is cosmopolitan today and has a very wide ( 82 to over $5,000 \mathrm{~m}$ ) bathymetric distribution (Reiswig 2002a; Lopes et al. 2011), but it is typical of bathyal depths. More common are stout and irregular dictyonal skeletons with swollen and tuberculated nodes (Fig. 6C, J, K) that belong to one species of Euretidae Zittel, 1877, possibly in Pararete Ijima, 1927. This genus possesses a choanosomal skeleton with similarly swollen and tuberculated nodes (see Reiswig and Wheeler 2002) and occurs today in the Japan-Indonesian region at depths between 100 and $800 \mathrm{~m}$ (Reiswig and Wheeler 2002).

Fragments of a sculptured lychniscosan skeleton (Fig. 6D, E) representing one species are very rare. Today, lychniscosan sponges are very rare and occur mostly in deep water (however, as shallow as $82 \mathrm{~m}$ is also possible) in the West Indies, Red Sea, Indonesia, and Philippines (Reiswig 2002b). This is the first record of lychniscosan sponges from the Miocene of the Paratethys. 


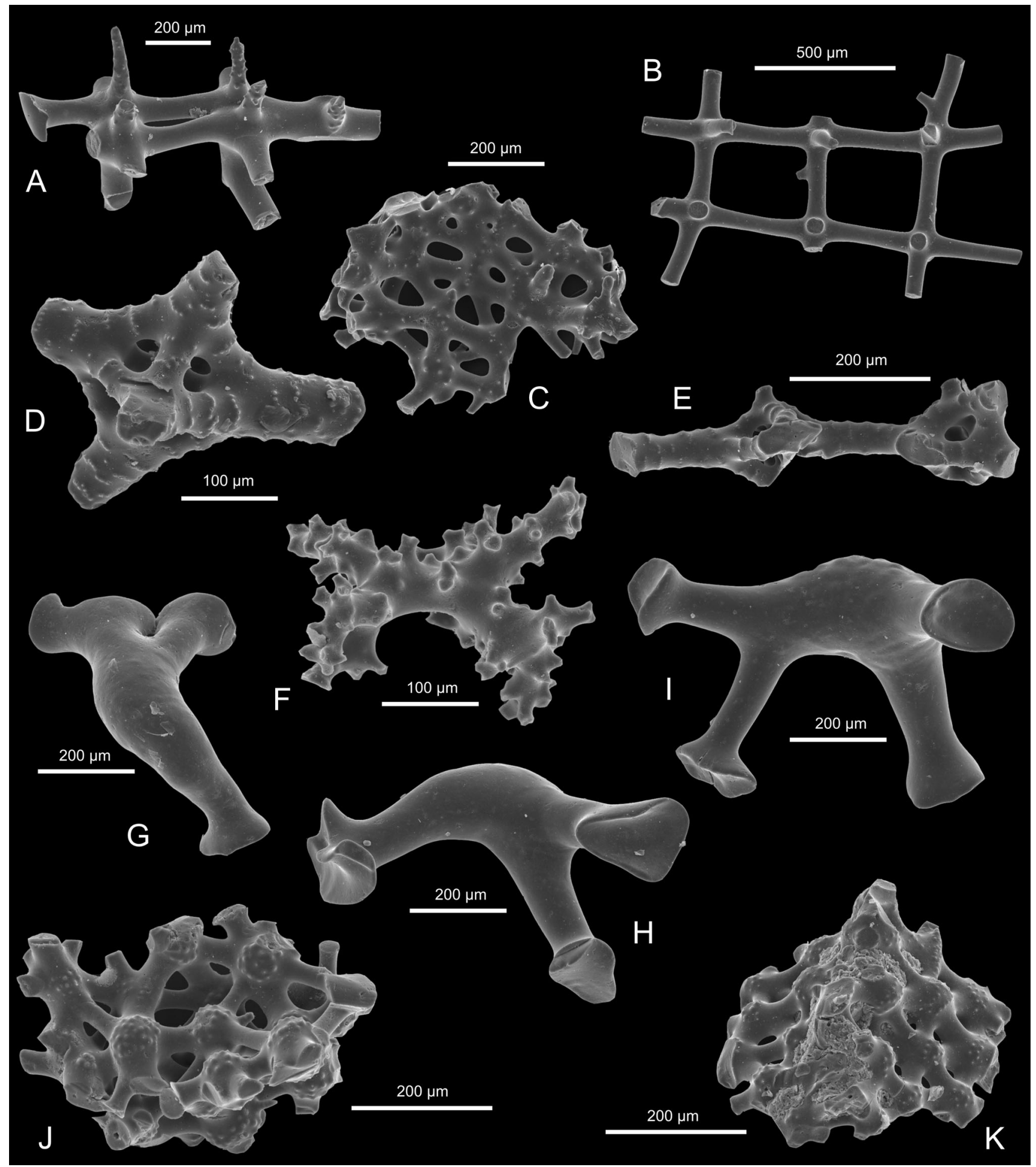

Fig. 6 Hexactinosid, lychniscosid, and lithistid spicules: $A, B$ fragment of dictyonal skeleton of hexactinosid species I; $C, J, K$ fragments of dictyonal hexactinosid skeleton II; $D, E$ fragment of dictyonal

A strange, $300 \mu \mathrm{m}$ long (partly broken) and thin spicule (Fig. 5P), which is finely acanthose, resembling some hexactinellid (Amphidiscosida) diactines has also been found. Amphidiscosid sponges are skeleton of lychniscosid sponge; $F$ lithistid rhizoclone desma; $G-$ I megaclone desmas of the lithistid Pleroma

typical bathyal dwellers (Tabachnick and Menshenina 2002a, b).

All together, at least two species of Hexactinosa, and one species of Lychniscosa were found at Cerová. It is 


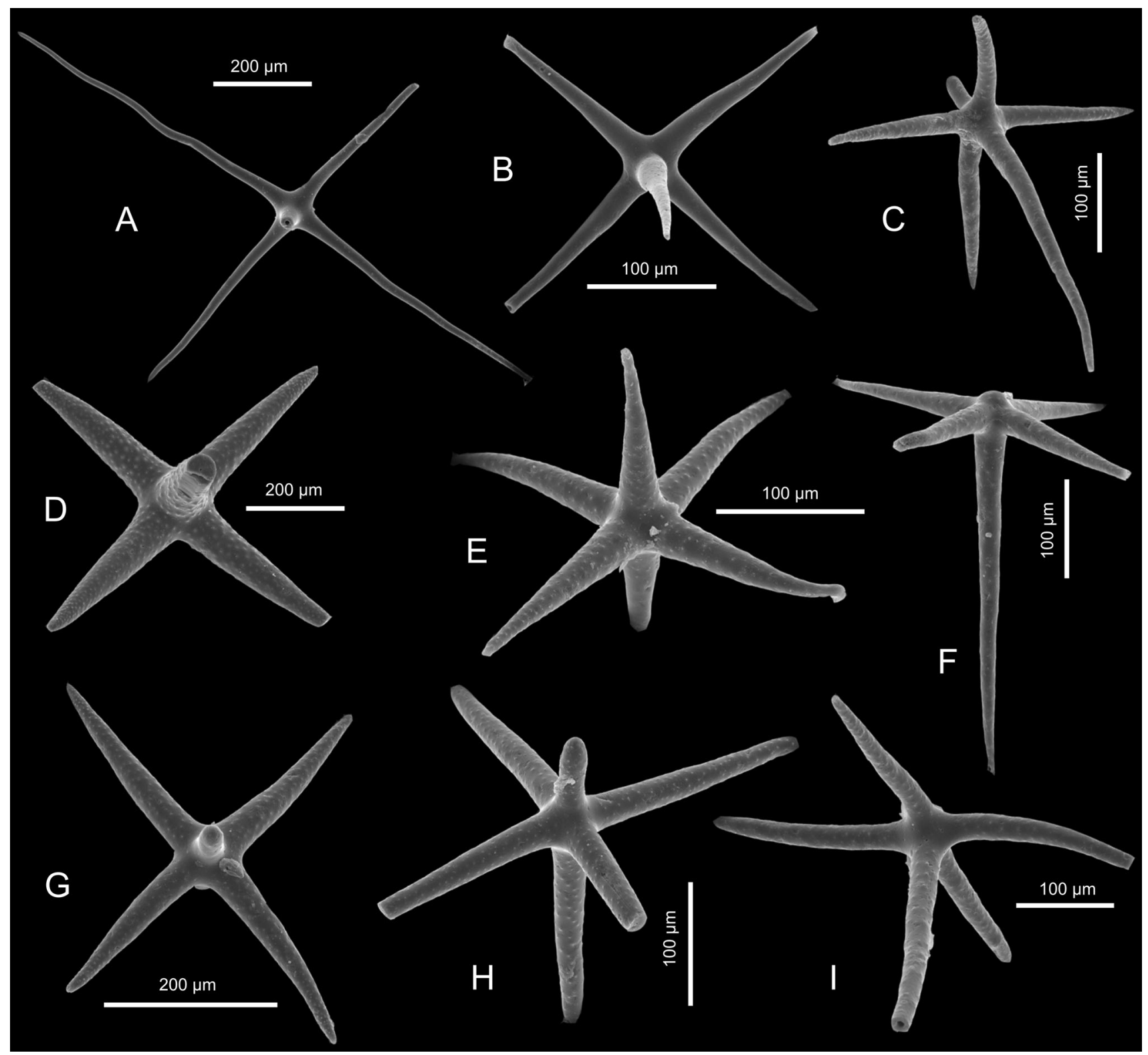

Fig. 7 Loose hexactinellid spicules: $A, B$ smooth pentactines that most probably belong to one species; $C-I$ tuberculated penta- and hexactines that most probably belong to one species

impossible to say if loose hexactines and pentactines belong to these species, or some other hexactinellids with unfused choanosomal skeleton, thus making it difficult to decide how many species of hexactinellid species occur at Cerová.

\section{Paleoecology and biogeography}

Sponge taxa above species level that occurred at Cerová during the terminal Early Miocene may occur today in both deep and relatively shallow waters. Most of them, however, are characteristic of relatively deep water today.
Hexasterophoran hexactinellid sponges, for example, are characteristic of bathyal depths, with the exception of special habitats such as submarine caves and/or fjords (Vacelet 1988; Vacelet et al. 1994), which is clearly not the present case. Some demosponges found at Cerová may have inhabited shallow waters, i.e., Geodia, but this genus has a very wide bathymetric range and is also common in bathyal waters, where it forms dense aggregations in socalled Ostur bottoms (Klitgaard and Tendal 2001). Lithistids, while very rare, also show this bathymetric range. On the other hand, the fact that they usually require hard (rocky) substrate, which was clearly absent in the visible section, suggests that also lithistids may be transported 
from shallower settings where such substrate was available for their colonization. Similarly, this may also be the case for myxillid, tedaniid, and agelasid sponges, which today inhabit shallow waters, but at Cerová co-occur with bathyal species. These sponges may also have been transported from shallower surrounding areas. One has also to note that the myxillid, tedaniid, and agelasid spicules are rare or even very rare, as are lithistid spicules.

Paleoecological interpretation of the sponge assemblage is supported by the other co-occurring groups of fossils. We can refer to the published results on benthic foraminifera, which were carefully evaluated for the sample interval 14-20 (Fig. 1, for methods applied see Schlögl et al. 2011a). Paleodepth estimations range between 240 and $330 \mathrm{~m}$, which is also in good accordance with coeval foraminiferal associations from the same lithofacies from the Styrian Basin in Austria (Spezzaferri et al. 2002). These upper bathyal conditions were tested on the composition of associated macrofaunal communities. Benthic gastropods are dominated by carnivores, scavengers (and/or predators) or parasites (more than $85 \%$, Harzhauser et al. 2011). Herbivores are extremely rare. Among the bivalves, the association consists of carnivores, chemosymbiotic, detritivores, and suspension feeders (Harzhauser et al. 2011). Such benthic mollusc composition indicates deposition in the aphytal zone and a very low contribution of transported taxa from shallower settings. Scaphopod Gadilina taurogracilis is considered as ancestor of Gadilina triquetra (Brocchi, 1814), which is widespread in Pliocene deposits of Italy. According to Ceregato et al. (2007), it is strictly bathyal and indicative of unstable deep marine environments. Even more significant is the crustacean assemblage, which is predominantly composed of deep-water genera such as Callianopsis, Agononida, Munidopsis, and Mursia (Hyžný and Schlögl 2011). Moreover, the calculated paleodepth range is in accordance with the optimal conditions of Recent nautiloid cephalopods, ancestors of which occur in great numbers in the Cerová section (Schlögl et al. 2011a). In addition to invertebrates, further support for deposition within a considerable depth of water can be provided by chondrichthyans (Underwood and Schlögl, accepted). Virtually all of the chondrichthyan taxa present in the studied deposits are related to forms that are either restricted to, or commonly present in, deep-water environments. Squaliforms dominate the assemblage in both number and diversity, and contain members of all three families of strongly heterodont squaliforms, today almost entirely limited to deep or open waters.

Most of the sponge genera found at Cerová have rather wide geographical distributions and occur in both Atlantic and Indo-West Pacific regions, with the notable exception of the myxillid Ectyonopsis, which occurs almost exclusively around Australia and in the Southern Ocean. The taxa with Miocene record are known from the Tethyan area. This pattern suggests Tethyan affinities of the studied sponge fauna, as well as the existence of good connections between Paratethys and Tethys during the Karpatian. Another known Karpatian assemblage of siliceous sponge spicules from Moravia (Pisera and Hladilová 2003) is dominated by astrophorid demosponges, while hexactinellids are very rare, which suggests that it characterizes shallower (although still deeper littoral) environment. On the other hand, the Badenian assemblage of spicules from Moravia, where amphidoscophoran hexactinellid spicules are common (Riha 1982, 1983), absent at Cerová, suggests even deeper water conditions during their deposition.

\section{Conclusions}

1. Well-preserved, intact specimens of "soft" siliceous demosponges were found in the Karpatian (Lower Miocene) deposits of the Cerová section (Slovakian part of the Vienna Basin, Paratethys), which are described here as a new genus and species, Paracinachyrella fossilis (Tetillidae, Demospongiae).

2. Dissociated spicules/skeleton fragments occurring in the same rocks witness that a rich assemblage of siliceous sponges inhabited the investigated region. Representatives of at least 13-15 demosponge species (including two species of lithistids that are reported for the first time from the Paratethys Miocene), belonging to 10 demosponge families have been recognized. Hexactinellids are represented by at least 3-4 species that belong to Hexactinosida and Lychniscosida, the latter reported for the first time from the Lower Miocene of the Paratethys.

3. Most investigated sponges characterize rather deep, most probably bathyal environment, an interpretation supported by the ecological character of the associated fauna. The presence of likely shallow-water elements as agelasids, myxillids, and tedaniids may indicate their transport from surrounding shallower environments. The likelihood of such transport is also supported by the presence of clearly allochthonous lithistid demosponge spicules, which require a hard substrate for attachment. Such environmental setting is absent at the Cerová section.

4. The majority of the sponges identified in the Cerová Karpatian deposits at genus/family level are widely distributed today and occur in Atlantic and Indo-West Pacific provinces. Those known from the Miocene occur in the Tethyan area. This indicates Tethyan 
affinities of the Cerová sponge fauna and confirms a good connection between Paratethys and Tethys during the latest Burdigalian (Karpatian).

Acknowledgments We thank Natália Hudáčková, Andrej Ruman, and Matúš Hyžný (Comenius University in Bratislava) for their help during the field and laboratory work, and Miroslav Hornáček, who provided a part of the studied material. M.Ł. and A.P. were funded by the Institute of Paleobiology, and J.S. was supported by the research Grants APVV 0644-10 and VEGA 2/0068/11. Special thanks are due to Alan Logan, University of New Brunswick (Canada) for linguistic improvements of the manuscript. We are indebted to Dr. Eduardo Hajdu (Museu Nacional, UFRJ, Brasil) and an anonymous reviewer for their help in improving our manuscript.

Open Access This article is distributed under the terms of the Creative Commons Attribution License which permits any use, distribution, and reproduction in any medium, provided the original author(s) and the source are credited.

\section{References}

Alexandrowicz, S.W. 1978. Spikule gąbek w piaskach galukonitowych $\mathrm{z}$ warstw skawińskich w Chełmie nad Przemszą. Sprawozdania z Posiedzeń Komisji Naukowych PAN, Oddziat w Krakowie 20: 399-401.

Alexandrowicz, S.W., and A. Tomaś. 1975. Zespół spikul gąbek z iłów mioceńskich rejonu Gliwic. Sprawozdania z Posiedzeń Komisji Naukowych PAN, Oddziat w Krakowie 18: 170-172.

Alvarez, B., and R.W.M. Van Soest. 2002. Family Bubaridae Topsent, 1894. In Systema Porifera A guide to the classification of sponges, vol. 1, ed. J.N.A. Hooper, and R.W.M. Van Soest, 748-754. Moscow: Kluwer Academic/Plenum.

Berggren, W.A., D.V. Kent, C.C.I.I.I. Swisher, and M.-P. Augry. 1995. A revised Cenozoic geochronology and chronostratigraphy. SEPM (Society for Sedimentary Geology), Special Publication 54: 129-212.

Bergquist, P.R., and J.J. Hogg. 1969. Free amino acid patterns in Demospongiae: a biochemical approach to sponge classification. Cahiers de Biologie Marine 10: 205-220.

Boury-Esnault, N. 2012. Annulastrella ornata. In World Porifera database, eds. R. W. M. Van Soest, N. Boury-Esnault, J. N. A. Hooper, K. Rützler, N. J. de Voogd, B. Alvarez de Glasby, E. Hajdu, A. Pisera, R. Manconi, C. Schoenberg, D. Janussen, K. R. Tabachnick, M. Klautau, B. Picton, M. Kelly, J. Vacelet, and M. Dohrmann. 2012. Accessed through: R. W. M. Van Soest, N. Boury-Esnault, J. N. A. Hooper, K. Rützler, N. J. de Voogd, B. Alvarez de Glasby, E. Hajdu, A. Pisera, R. Manconi, C. Schoenberg, D. Janussen, K. R. Tabachnick, M. Klautau, B. Picton M., Kelly, J. Vacelet, and M. Dohrmann. World Porifera database at http://www.marinespecies.org/porifera/porifera. php?p=taxdetails\&id=597261. Accessed 23 July 2012.

Bowerbank, J.S. 1862. On the anatomy and physiology of the Spongiadae Part III On the generic characters, the specific characters, and on the method of examination. Philosophical Transactions of the Royal Society 152(2): 1087-1135.

Brocchi, G.V. 1814. Conchiologia fossile subapennina, con osservazioni geologiche sugli Apennini e sul suolo adiacente. [Fossil shells from the Subapennin and geological observations on the apennin and the surrounding area.], 1-712. Milano: Dalla Stamperia Reale (in Italian).
Bukry, D. 1978. Cenozoic coccolith, silicoflagellate, and diatom stratygraphy, Deep Sea Drilling Project Leg 44. In Initial Reports of the Deep Sea Drilling Project, ed. R.E. Sheridan, et al., 807-864. Benson 44, U.S. Washington: Government Printing Office.

Burton, M. 1959. Sponges. 151-281. In Scientific Reports. John Murray Expedition, 1933-34. 10 (5). [London: British Museum (Natural History)].

Carter, H.J. 1871. On fossil sponge-spicules of the Greensand compared with those of existing species. Annals and Magazine of Natural History 7(38): 112-141.

Carter, H.J. 1873. On two new species of Gummineae, with special and general observations. Annals and Magazine of Natural History (4)12 (67): 17-30.

Carter, H.J. 1874. Descriptions and figures of deep-sea sponges and their spicules from the Atlantic Ocean, dredged up on board H.M.S.'Porcupine', chiefly in 1869; with Figures and Descriptions of some remarkable Spicules from the Agulhas Shoal and Colon, Panama. Annals and Magazine of Natural History (4) 14 (79): 207-221, 245-257.

Carter, H.J. 1875. Notes Introductory to the Study and Classification of the Spongida. Part II. Proposed Classification of the Spongida. Annals and Magazine of Natural History (4) 16 (92): 126-145, 177-200.

Carter, H.J. 1883. Contributions to our knowledge of the Spongida. Annals and Magazine of Natural History (5) 12 (71): 308-329.

Ceregato, A., S. Raffi, and D. Scarponi. 2007. The circolittoral/ bathyal paleocommunities in the middle Pliocene of Northern Italy. The case of the Korobkovia oblonga-Jupiteria concava. Geobios 40(59): 555-572.

Cicha, I., and F. Rögl. 2003. Definition of the Karpatian Stage. 15-20. In The Karpatian, a Lower Miocene stage of the Central Paratethys, ed. R. Brzobohatý, I. Cicha, M. Kováč, and F. Rögl, 360. Brno: Masaryk University.

Dendy, A 1922. Report on the Sigmatotetraxonida collected by H.M.S. 'Sealark' in the Indian Ocean. 1-164, pls 1-18. In Reports of the Percy Sladen Trust Expedition to the Indian Ocean in 1905, volume 7. Transactions of the Linnean Society of London (2), 18(1).

Finks, R.M., K. Hollocher, and K.J. Thies. 2011. A major Eocene sponge fauna (Castle Hayne Formation, North Carolina). Journal of the North Carolina Academy of Science 127: 39-175.

Gomez, P. 2006. Yucatania clavus, new genus and species of the family Thrombidae (Porifera: Demospongiae: Astrophorida) from the continental shelf of Yucatan, Mexico. Proceedings of the Biological Society of Washington 119: 339-345.

Grant, R.E. 1836. Animal kingdom. In The cyclopaedia of anatomy and physiology, ed. R.B. Todd, 107-118. London: Sherwood, Gilbert, and Piper.

Gray, J.E. 1867. Notes on the arrangement of sponges, with the descriptions of some new genera. Proceedings of the Zoological Society of London 1867(2): 492-558.

Gray, J.E. 1872. Notes on the Classification of the Sponges. Annals and Magazine of Natural History (4) 9(54): 442-461.

Harzhauser, M., and J. Schlögl. 2012. Lepadiform and scalpelliform barnacles from the Oligocene and Miocene of the Paratethys Sea. Palaeontology 55(5): 923-936.

Harzhauser, M., O. Mandic, and J. Schlögl. 2011. A late Burdigalian bathyal mollusc fauna from the Vienna Basin (Slovak Republic, Karpatian). Geologica Carpathica 62: 211-231.

Hentschel, E. 1911. Tetraxonida. 2. Teil. In Die Fauna SüdwestAustraliens.Ergebnisse der Hamburger südwest-australischen Forschungsreise 1905, ed. W. Michaelsenand, and R. Hartmeyer, 279-393. Jena: Fischer.

Hinde, G.J., and W.M. Holmes. 1892. On the sponge remains in the lower tertiary strata near Oamaru, Otago, New Zealand. Journal of the Linnean Society of London, Zoology 24: 177-262. 
Hooper, J.N.A., and R.W.M. Van Soest (eds.). 2002. Systema Porifera: a guide to the classification of Sponges. Kluwer Academic/ Plenum: New York, NY 1-1101, 1103-1708 (2 volumes).

Hurcewicz, H. 1991. Igły gąbek w utworach badenu okolic Korytnicy. Przeglad Geologiczny 11-12: 547-548.

Hyžný, M., and J. Schlögl. 2011. An Early Miocene deep-water decapod crustacean faunule from the Vienna Basin (Western Carpathians, Slovakia). Palaeontology 54: 323-349.

Hyžný, M., N.L. Bruce, and J. Schlögl. 2013. An appraisal of the fossil record for the Cirolanidae (Malacostraca: Peracarida: Isopoda: Cymothoida), with a description of a new cirolanid isopod crustacean from the Early Miocene of the Vienna Basin (Western Carpathians). Palaeontology 56: 615-630.

Ijima, I. 1927. The Hexactinellida of the Siboga Expedition. In Siboga-Expeditie. Uitkomsten op zoologisch, botanisch, oceanographisch en geologisch gebied verzameld in Nederlandsch Oost-lndië 1899- 1900 aan boord H.M. 'Siboga' onder commando van Luitenant ter zee le kl. G.F. Tydemann. 106 (Monographie VI), ed. M. Weber. Leiden: E.J. Brill. (p. i-viii, 1-383, pls I-XXVI).

Klitgaard, A.B., and O.S. Tendal. 2001. Ostur- "Cheese" bottomssponge dominated areas in the Faroese shelf and slope areas. In Marine Biological Investigations and Assemblages of Benthic Invertebrates from the Faroe Islands, ed. G. Bruntse, and O.S. Tendal, 13-21. The Faroe Islands: Kaldbak Marine Biological Laboratory.

Lopes, D.A., E. Hajdu, and H.M. Reiswig. 2011. Taxonomy of Farrea (Porifera, Hexactinellida, Hexactinosida) from the southwestern Atlantic, with description of a new species and a discussion on the recognition of subspecies in Porifera. Canadian Journal of Zoology 89: 169-189.

Lundbeck, W. 1910. Porifera. (Part III.) Desmacidonidae (pars.). The Danish Ingolf-Expedition 6(3): 1-124.

Mostler, H. 1986. Neue Kieselschwämme aus den Zlambachschichten (Obertrias, Nördliche Kalkalpen) [New siliceous sponges from the Zlambach Beds (Upper Triassic, northern Calcareous Alps)]. Geologisch-Paläontologische Mitteilungen Innsbruck 13: 331-361.

Mostler, H. 1990. Mikroskleren von Demospongien (Porifera) aus dem basalen Jura der Nördlichen Kalkalpen. Geologisch-Paläontologische Mitteilungen Innsbruck 17: 119-142.

Olsson, R.K. 1964. Praeorbulina Olsson, a new foraminiferal genus. Journal of Paleontology 38: 770-771.

Papp, A., and K. Turnovski. 1953. Die Entwicklung der Uvigerinen im Vindobon (Helvet und Torton) des Wiener Beckens. Jahrbuch der Geologischen Bundesanstalt Wien 91: 117-142.

Piller, W.E., M. Harzhauser, and O. Mandic. 2007. Miocene Central Paratethys stratigraphy: current status and future directions. Stratigraphy 4: 151-168.

Pisera, A. 2006. Palaeontology of sponges: A review. Canadian Journal of Zoology 84: 242-262.

Pisera, A., and C. Lévi. 2002a. 'Lithistid' Demospongiae. In Systema Porifera. A guide to the classification of sponges, vol. 1, ed. J.N.A. Hooper, and R.W.M. Van Soest, 299-301. Moscow: Kluwer Academic/Plenum.

Pisera, A., and C. Lévi. 2002b. Family Pleromidae Sollas, 1888. In Systema Porifera. A guide to the classification of sponges, vol. 1, ed. J.N.A. Hooper, and R.W.M. Van Soest, 321-326. Moscow: Kluwer Academic/Plenum.

Pisera, A., and S. Hladilová. 2003. Siliceous sponge spicules from the Karpatian of the Carapthian Foredeep in Moravia. In The Karpatian, a Lower Miocene stage of the Central Paratethys, ed. R. Brzobohatý, I. Cicha, I. Cicha, M. Kováč, and F. Rögl, 360. Brno: Masaryk University. (189-192).

Pisera, A., M. Cachao, and C. da Silva. 2006. Siliceous sponge spicules from the Miocene Mem Moniz marls (Portugal) and their environmental significance. Rivista Italiana de Paleontologia 112: 287-299.

Reiswig, H. 2002a. Family Farreidae Gray, 1872. In Systema Porifera. A guide to the classification of sponges, vol. 2, ed. J.N.A. Hooper, and R.W.M. Van Soest, 1332-1340. Moscow: Kluwer Academic/Plenum.

Reiswig, H. 2002b. Family Aulocystidae Sollas, 1887. In Systema Porifera. A guide to the classification of sponges, vol. 2, ed. J.N.A. Hooper, and R.W.M. Van Soest, 1378-1382. Moscow: Kluwer Academic/Plenum.

Reiswig, H., and B. Wheeler. 2002. Family Euretidae. In Systema Porifera. A guide to the classification of sponges, vol. 2, ed. J.N.A. Hooper, and R.W.M. Van Soest, 1301-1340. Moscow: Kluwer Academic/Plenum.

Ridley, S.O., and A. Dendy. 1886. Preliminary report on the Monaxonida collected by H.M.S. 'Challenger'. Annals and Magazine of Natural History 5(18): 325-351. (470-493).

Riha, J. 1982. Jehlice hub Karpatu a Badenu (Tercier-Miocen) karpatske predhlubne na Morave. Casopis Moravskeho Muzea. Vedy Prirodni 67: 31-40.

Riha, J. 1983. Sponge spicules of the Karpatian and Lower Badenian of the Carpathian Foredeep in Moravia, Czechoslovakia. Knihovnicka Zemniho Plynu a Nafty 4: 171-194.

Rögl, F., S. Ćorić, G. Daxner-Höck, M. Harzhauser, O. Mandic, L. Švábenická, and I. Zorn. 2003. Correlation of the Karpatian Stage. In The Karpatian, a Lower Miocene stage of the Central Paratethys, ed. R. Brzobohatý, I. Cicha, M. Kováč, and F. Rögl, 27-34. Brno: Masaryk University.

Rützler, K. 2002. Family Alectonidae Rosell, 1996. In Systema Porifera. A guide to the classification of sponges, vol. 1, ed. J.N.A. Hooper, and R.W.M. Van Soest, 281-290. Moscow: Kluwer Academic/Plenum.

Schlögl, J., R. Chirat, V. Balter, M. Joachimski, N. Hudáčková, and F. Quillévéré. 2011. Aturia of the Miocene Paratethys: an exceptional window in nautilid habitat and lifestyle. Palaeogeography, Palaeoclimatology, Palaeoecology 308: 330-338.

Schmidt, O. 1870. Grundzüge einer Spongien-Fauna des atlantischen Gebietes. Wilhelm Engelmann: Leipzig: iii-iv, 1-88.

Schrammen, A. 1910. Die Kieselspongien der oberen Kreide von Nordwestdeutschland. I. Teil. Tetraxonia, Monaxonia und Silicea incertae sedis. Palaeontographica 5 (supplement): 1-175.

Schrammen, A. 1924. Zur Revision der Jura-Spongien von Suddeutschlands.-Jahresberichte und Mitteilungen Oberrheinischen Geologischen Vereins 125-154.

Sollas, W.J. 1885. A Classification of the Sponges. Annals and Magazine of Natural History (5) 16 (95): 395.

Sollas, W.J. 1886. Preliminary account of the Tetractinellid sponges Dredged by H.M.S. 'Challenger' 1872-76. Part I. The Choristida. Scientific Proceedings of the Royal Dublin Society (new series) 5: $177-199$.

Sollas, W.J. 1888. Report on the Tetractinellida collected by H.M.S. Challenger, during the years 1873-1876. Report on the Scientific Results of the Voyage of H.M.S. Challenger, 1873-1876. Zoology 25(63): 1-458.

Spezzaferri, S., S. Ćorić, J. Hohenegger, and F. Rögl. 2002. Basinscale paleobiogeography and paleoecology: an example from Karpatian (Latest Burdigalian) benthic and planktonic foraminifera and calcareous nannofossils from the Central Paratethys. Geobios 35: 241-256.

Špička, V., and I. Zapletalová. 1964. Nástin korelace karpatu v československé části vídeňské pánve. Sborník Geologických Věd, Geologie 8: 125-160.

Tabachnick, K.R., and L.L. Menshenina. 2002a. Family Hyalonematidae Gray, 1857. In Systema Porifera. A guide to the classification of sponges, vol. 2, ed. J.N.A. Hooper, and R.W.M. Van Soest, 1244-1275. Moscow: Kluwer Academic/Plenum. 
Tabachnick, K.R., and L.L. Menshenina. 2002b. Family Pheronematidae Gray, 1870. In Systema Porifera. A guide to the classification of sponges, vol. 2, ed. J.N.A. Hooper, and R.W.M. Van Soest, 1279-1292. Moscow: Kluwer Academic/Plenum.

Todd, R., P.E. Cloud, D. Low, and R.G. Schmidt. 1954. Probable occurrence of Oligocene on Saipan. American Journal of Science 252: 673-682.

Topsent, E. 1894. Une réforme dans la classification des Halichondrina. Mémoires de la Société zoologique de France 7: 5-26.

Topsent, E. 1898. Eponges nouvelles des Açores. (Première serie). Mémoires de la Société zoologique de France 11: 225-255.

Uriz, M.J. 2002a. Family Geodiidae Gray, 1867. In Systema Porifera. A guide to the classification of sponges, vol. 1, ed. J.N.A. Hooper, and R.W.M. Van Soest, 134-140. Moscow: Kluwer Academic/Plenum.

Uriz, M.J. 2002b. Family Thrombidae Sollas, 1888. In Systema Porifera. A guide to the classification of sponges, vol. 1, ed. J.N.A. Hooper, and R.W.M. Van Soest, 163-164. Moscow: Kluwer Academic/Plenum.

Vacelet, J. 1999. Planktonic armoured propagules of the excavating sponge Alectona (Porifera: Demospongiae) are larvae: evidence from Alectona wallichii and A. mesatlantica sp. nov. Memoirs of the Queensland Museum 44: 627-642.

Vacelet, J. 1988. Indication de profondeur donnes par les Spongiaires dans les milieux banthiques actuels. Géologie Méditerrannée 15: $13-26$.

Vacelet, J., N. Boury-Esnault, and J.G. Haremelin. 1994. Hexactinellid cave, a unique deep-sea habitat in the scuba zone. DeepSea Research 41: 965-973.
Van Soest, R.W.M. 2002. Family Agelasidae Verrill, 1907. In Systema Porifera. A guide to the classification of sponges, vol. 1, ed. J.N.A. Hooper, and R.W.M. Van Soest, 819-823. Moscow: Kluwer Academic/Plenum.

Van Soest, R.W.M. 2002. Family Myxillidae Dendy, 1922. In Systema Porifera. A guide to the classification of sponges, vol. 1, ed. J.N.A. Hooper, and R.W.M. Van Soest, 602-620. Moscow: Kluwer Academic/Plenum.

Van Soest, R.W.M., N. Boury-Esnault, J. Vacelet, M. Dohrmann, D. Erpenbeck, N.J. De Voogd, N. Santodomingo, B. Vanhoorne, M. Kelly, and J.N.A. Hooper. 2012. Global diversity of sponges (Porifera). PLoS ONE 7(4): e35105.

Verrill, A.E. 1907. The Bermuda Islands: part V. An account of the Coral Reefs (Characteristic Life of the Bermuda Coral Reefs). Porifera: Sponges. Transactions of the Connecticut Academy of Arts and Sciences 12: 330-344.

Wiedenmayer, F. 1994. Contribution to the knowledge of postPaleozoic neritic and archibenthal sponges (Porifera). Schweizerische Palaeontologische Abhanlungen 116: 1-147.

Wilson, H. V. 1925. Silicious and horny sponges collected by the U.S. Fisheries Steamer 'Albatross' during the Philippine Expedition, 1907-10. In Contributions to the biology of the Philippine Archipelago and adjacent regions, 273-532. Bulletin of the United States National Museum 100 (2, part 4). 